$$
R_{\mathrm{p}}=-\frac{\mathrm{d}[\mathrm{A}]}{\mathrm{d} t}=k_{\mathrm{p}}[\mathrm{P} \cdot][\mathrm{A}]
$$

定常状態を仮定すると次の関係が得られる。

$$
\frac{1}{[\mathrm{~A}]}-\frac{1}{[\mathrm{~A}]_{0}}=\frac{k_{\mathrm{p}}}{k_{\mathrm{t}}} \varphi_{\mathrm{A}} I t
$$

$[\mathrm{A}]_{0}$ は $1: 1$ モノマー錯体の初期濃度で [A] は $t$ 時間後の 濃度である。変形して

$$
\frac{Y}{1-Y}=\frac{k_{\mathrm{p}} \varphi_{\mathrm{A}}}{k_{\mathrm{t}}} I[\mathrm{~A}]_{0} t
$$

となる。ここに $Y$ は生成ポリマーの分率である。

塊状共重合の場合, この式で図 3 の值を整理すると図 10 のよ

うになり，この関係はほぼ満足されている。

一方，モノマー濃度と共重合速度との関係を示す図 8 を上式に
よって整理すると図 11 のようになり,この場合も直線関係が得 られ上式を渾足している。

これらの結果は，上述の仮定がほぼ満足されているとみてよい であろ5※1。溶液系では，重合速度に著しい加速効果が認められ るが,これは，溶媒の放射線による分解に基ついた開始反応速度の 增大と,モノマ一の溶媒和との両方に基因するるのと考えられる。

結論として，無水マレイン酸と $\alpha$-メチルスチレンの液相にお ける放射線共重合は，ラジカル機構で進み，モノマー混合組成の 広い範囲にわたって，交互共重合体が得られることが判明した。 (昭和 38 年 11 月, 高分子討論会にて講演(名古屋))

※1 一般的には 2 分子停止も無視できないと考えられるので， 広い実験条件の範囲では, 厳密には上述の関倸は成立しない。

\title{
被照射ポリブテンー1 のラジカル種におよほす微細構造の影響十
}

(昭 和 39 年 7 月 24 日受 理)

\author{
福田建二*・楠本 直 ${ }^{* *}$.河野岩造*・高柳素夫***
}

\begin{abstract}
試料のアイソタクチックポリブテン-1 は，その溶融物を室温で結晶化させた部分結晶化 S-1 と，ガラス温度以下に急 冷して得た無定形物 S-2 の三つを用い，これを液体窒素温度で䄪 $10^{7} \mathrm{r}$ の 線を照射したのち，ESR 測定を行なった。 $\mathrm{ESR}$ スペクトルは $-120^{\circ} \mathrm{C}$ 以下では 6 本構造を含むと思われる幅の広い形を示すが，温度を上げるとともに鋭くなり， $-70^{\circ} \mathrm{C}$ 以上では無定形試料には 4 本構造が, 部分結晶試料には室温付近で 8 本構造が明らかになる。さらに, 一 $60^{\circ} \mathrm{C}$ 付 近の S-1 のスペクトルから同温度での 8 本構造スペクトルを差し引いたものは S-2 の 4 本構造スペクトルに等しくなる ことから，4 本構造が両試料の無定形部分に共通であり，8本構造は部分結晶化試料の結晶領域に特有のものであること が証明された。また，これら 4 本および 8 本構造を示すラジカルは,それぞれ 3 個拉よび 7 個のプロトンとの同等な相互 作用を持つものであり, 照射による発生ガスの質量スペクトル, 照射前後の極限粘度の変化などから考え合わせると, 4 本構造を示すラジカル種は主鎖の切断により生じたもので, 結晶領域中ではプロトンの移動によって 4 本構造から 8 本構 造に变ったものと推論した。
\end{abstract}

\section{1 緒言}

近年, ESR 法による高分子固体の研究結果がしばしば報告され ている。そのなかで, 放射線化学の一環としての $\gamma$ 線などの放 射線による生成ラジカルの同定あるいはラジカル重合過程に括け るラジルの挙動のほかに，ラジカルとそれを囲むふんい気（ここ では高分子固体の微細構造を意味する）の影響を、ラジカルの反 応性と結びつけて究明することが行なわれている1)。著者らは, この問題をより合理的に解明するため, 試料としては物理的処理 によって容易にその微細構造を変え得るポリ- $\alpha$-オレフィン類の ろちから，アイソタクチックポリブテンー1 を選定した。この物 質の物性については, Woodward らの核磁気共鳴2)扣よび粘弾性 测定 $^{3)}$ ，また著者らの粘弾性测定 ${ }^{4)}$ その他 ${ }^{5}$ がある。結晶構造につ

$\dagger$ 本報告を「ポリオレフィンの磁気共鳴に関する研究（第 1 報)」とする。

* 九州大学教養部物理学教室 : 福岡市大坪町.

** 九州大学工学部原子核工学教室 : 福岡市箱崎町.

*** 九州大学工学部応用化学教室: 福岡市箱崎町.

1) 大西, 池田, 仁田, 高分子 10，615 (1961).

2) A. E. Woodward, A. Odajima, R. A. Wall, J. Chem. Phys. 65, 1384 (1961).

3) A. E. Woodward, J. A. Sawer, R. A. Wall, J. Polymer Sci. 50, 117 (1961).
いては，結晶化の方法により三つの結晶変態を取ることが Natta らによって報告されている6゙が，ESR 測定に関しては，ポリプロ ピレン7,8,9) を除いて，他のポリ $\alpha$-オレフィン類とともにほとん ど報告が見られないようである。

著者らがここに用いたアイソタクチックポリブテンー1 は，適 当な物理的処理により，ほぼ完全な無定形物ともっとも安定した 結晶構造をもつ部分結晶化物が得られ，無定形物からの ESR ス ペクトルを部分結晶化物から得られたスペクトルより差し引けば, 結晶領域に由来する分を分離することが可能である。したがって 結晶，無定形両域に拈ける分子的環境がラジカルの挙動に㧊よぼ す影響を分離して観測することが可能となろう。

\section{2 実 験 方 法}

\section{$2 \cdot 1$ 試料の調製}

アイソタクチックポリブテン-1, Petro-tex (Petro-tex 社製

4) H. Yasuda, M. Takayanagi, RPPPJ. 7, 245 (1964).

5) J. Boor, J. C. Mitchell, J. Polymer Sci. 52, 59 (1963).

6) G. Natta, Makromol. Chem. 65, 139 (1963).

7) D. Libby, M. G. Ormered, A. Charlesby, Polymer 1, 212 (1960).

8) S. Ohnishi, Y. Ikeda, M. Kashiwagi, I. Nitta, Polymer 1, $212(1960)$

9）大西，柏木，池田，仁田，同位体と放射線 1，210(1958). 
品）を $160^{\circ} \mathrm{C}$ で 10 分間溶融状態に保ち，これを厚さ約 $3 \mathrm{~mm}$ の板状にプレス成形後, 室温で 1 週間以上放置して結晶化させた 部分結晶化試料（以下 S-1 と略記する）と，これを適当な大き さに切断後再び溶融したものを液体窒素中に急冷して, 透明な無 定形試料（以下 S-2 と略記する）を作成した。

Natta らによれば, アイソタクチックポリブテン-1は，3 種の 結晶变態 (Modification I, II, II) を持っている。溶融物からの 結晶化，あるいは高温に㧍ける溶媒蒸発による結晶化過程を経た あのは Mod. II であり，これを室温に放置すると Mod. I 飞変 わる。Mod. III はキシレンなどの希薄溶液から析出したものに認 められる。著者らが作成した試料 S-1 は，その作成条件から Mod. I 飞相当する。図 1 には $90^{\circ} \mathrm{C}$ で溶媒蒸発 (キシレン使用) して得たフィルムを室温で放置した場合の赤外吸収スペクトルの 経時変化を示す。各結晶变態に特有の吸収帯の $ち$ ちから代表的な

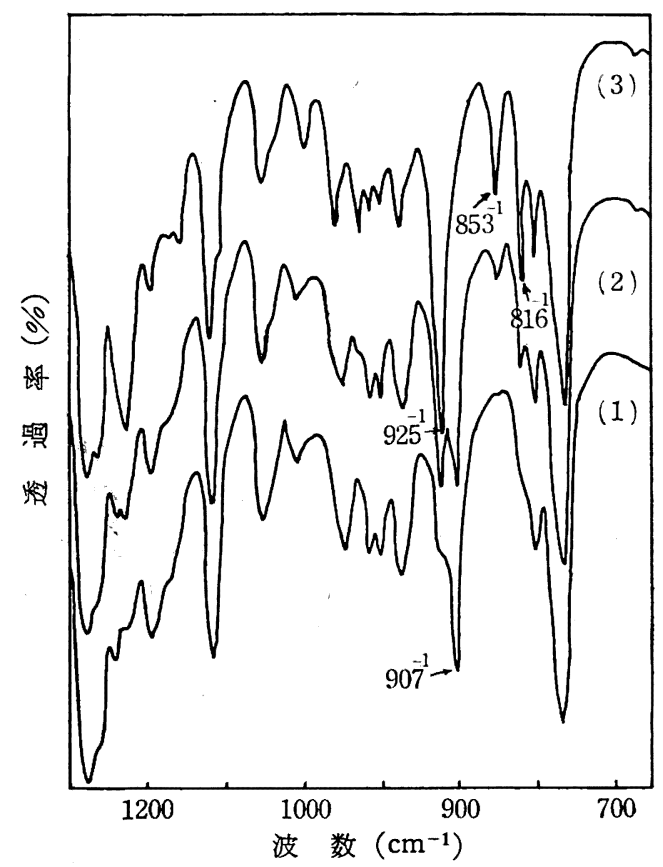

図 1 ポリブテン-1 皮膜の赤外吸収スペクトル

(1) : Mod. II, $0 \mathrm{hr}$, (2): Mod. I, II, $5 \mathrm{hr}$, (3):Mod. I, $24 \mathrm{hr}$

例を示せば，Mod. I には $925,853,816 \mathrm{~cm}^{-1}$, Mod. II には $907 \mathrm{~cm}^{-1}$ (図中矢印) などがあり，図 1 では放置時間の経過とと も飞 Mod. II 飞特有の吸収帯が減じる一方, Mod. I 飞特有の吸 収帯が現われ，24 時間後には Mod. I に基づく吸収帯のみが見 られる。また, S-1 の密度は浮沈法で $0.9116 \mathrm{~g} / \mathrm{ml}$ であり, この 値より算出した結晶化度は $54 \%$ である（ただし $\rho_{\mathrm{c}}=0.95 \mathrm{~g} / \mathrm{m} l$, $\left.\rho_{\mathrm{a}}=0.86 \mathrm{~g} / \mathrm{m} l\right)$ 。ESR 用の試料は，これを試料空胴そ万入部の外

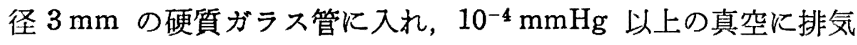
後溶封した。S-2 は排気溶封などの操作中に結晶化を起こさない よ5, ガラス温度以下に保つ注意が必要で, 常に $-30^{\circ} \mathrm{C}$ 以下に 保った。質量スペクトル用の試料は，ブレークシールを付けた硬 質ガラス管内にそれぞれ S-1，S-2 を排気封入したものを用い た。

\section{$2 \cdot 2 r$ 線照射}

線源には ${ }^{60} \mathrm{Co}$ (3000 curie) を用い $4 \times 10^{5} \mathrm{r} / \mathrm{hr}$ の線量率で 3

10) G. Natta, Makromol. Chem. 35, 94 (1960).

11) 西岡, 高分子化学 19, 667 (1962). $\times 10^{7} \mathrm{r}$ の照射を液体空素中で行なった。

\section{$2 \cdot 3$ ESR その他の測定}

ESR 測定には日立 MPU 型磁気共鳴分析計を用いた。試料は 試料空胴を貫く石英二重管内に杂万人し，その温度は二重管内を 流れる窒素ガスを温度調節することによって， $\pm 1^{\circ} \mathrm{C}$ 以内の精度 に保った。 $\gamma$ 線照射によって封管内に発生したガスを検出するた めに質量分析を行なった。試料中のラジカルを反応消失させるた め, この場合測定前に $100^{\circ} \mathrm{C} て ゙ 1$ 時間の熱处理を行なっている。 分子量に対する照射の影響を知るために, 極限粘度を S-1 の照 射前後について測定した。測定温度は $40^{\circ} \mathrm{C}$, 溶媒は nーヘプタン を用いた。

\section{3 実 験 結 果}

\section{$3 \cdot 1$ ESR スペクトルの温度変化}

図 2 には，S-1 を低温から高温へ昇温して得られた ESR スペ クトルの温度変化を示す。スペクトルは低温より $-120^{\circ} \mathrm{C}$ に至る まではぼやけた 6 本構造を含む形を保っているが，それ以上の温

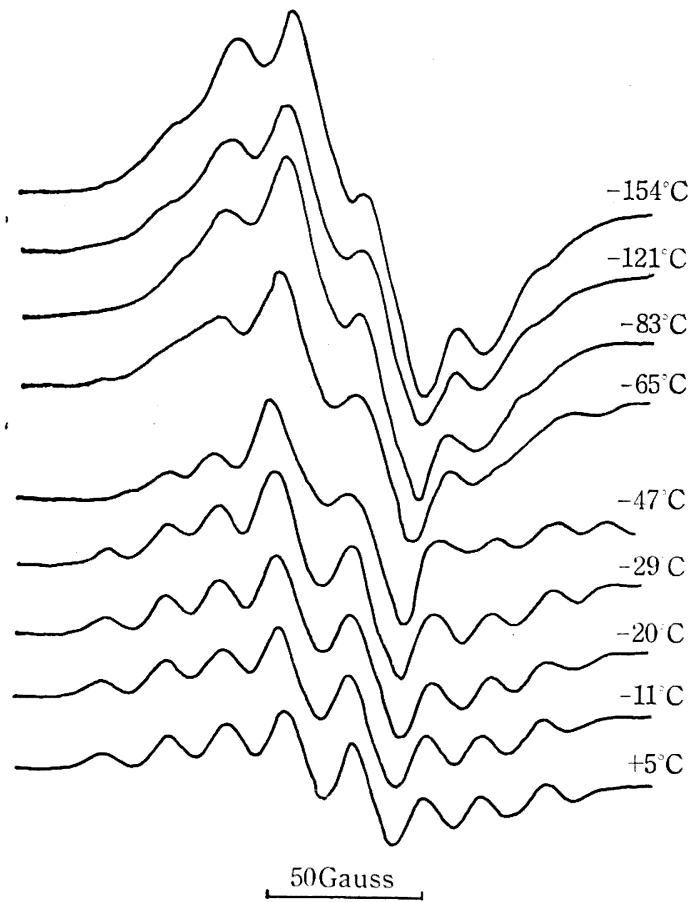

図 2 S-1 の ESR スペクトル温度変化

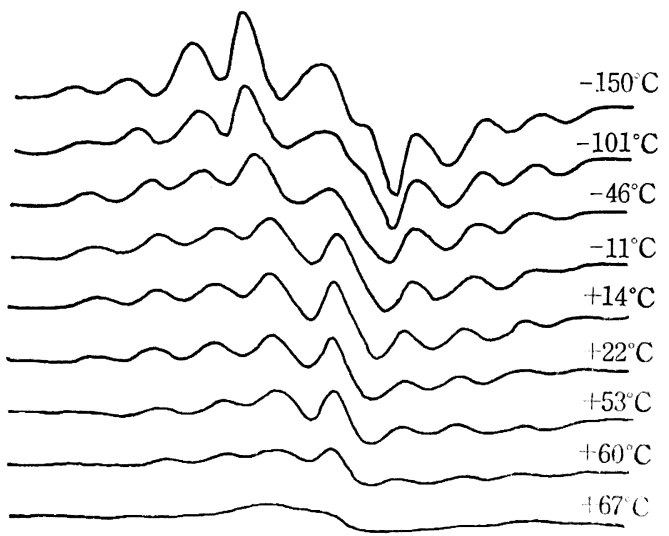

50Gauss

図3 S-1 の ESR スペクトル（8 本構造）温度变化 


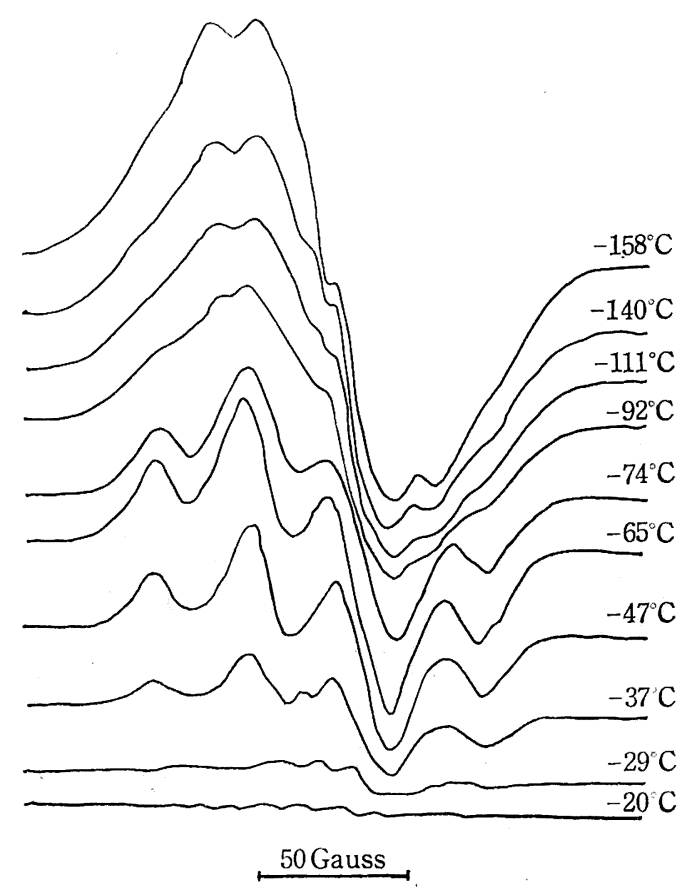

困 4 S-2 の ESR スペクトル温度変化

度域でしだいに鋭さを增して行き，さらに $-70^{\circ} \mathrm{C}$ 以上では図形 に著しい変化が現われる。齐なわち, 昇温に伴って8 本構造が出 始め, 室温に至ってきわめて明りょ5になる。図 3 は, 室温で得 られた 8 本構造をもつ試料の温度を变杂た場合のスペクトルの温 度変化で, 図 2 の変化が非可逆であるのに対し, 室温以下では可 逆的であり， $-70^{\circ} \mathrm{C}$ 付近から図形が変化しているが，室温以上 の変化は 8 本構造の強度が 減少するのみで, $70^{\circ} \mathrm{C}$ でスペクトル が消失する。図 4 は S-2 についてのスペクトルの温度变化で, S-1 に比較してさらにぼやけた図形が観測される。この場合, $-120^{\circ} \mathrm{C}$ 付近で 6 本構造を含み, 温度上昇飞伴ってその形が鋭く なることは，S-1 の場合と同じであるが， $-70^{\circ} \mathrm{C}$ 付近から現われ るスペクトルの形の変化は，S-1 に見られた 8 本構造の出現では

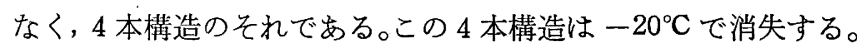

\section{$3 \cdot 2 \gamma$ 線照射による発生ガス}

図 5 には $\gamma$ 線照射による S-1 の発生ガスの水素を除いた質量 スペクトル図を示す。これを炭化水素の標準スペクトル ${ }^{12}$ と比較

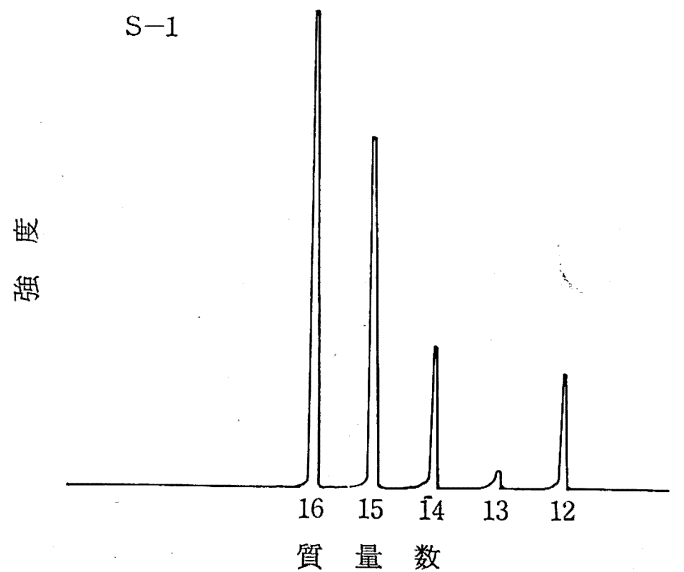

図 $5 r$ 線照射による S-1 からの発生ガスマススペクトル
することにより定性的にメタンの存在が知れる。

\section{$3 \cdot 3 \gamma$ 線照射による極限粘度の変化}

図6に $\gamma$ 線照射による S-1 Kついて測定した極限粘度を示 す。これによれば, $\gamma$ 線照射により極限粘度は照射前の $1 / 2$ 程度 に低下しているのが認められる。

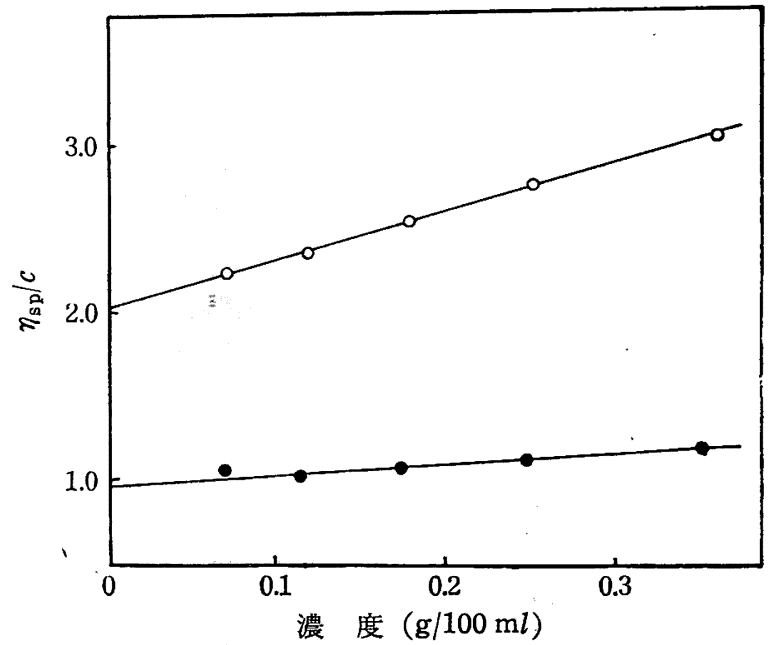

図 $6 r$ 線照射前後に拈ける S-1 の比粘度
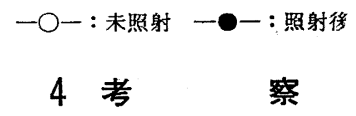

4・1·試料の微細構造と Hyperfine structure (hfs)

S-1 抢よび S-2 が $-70^{\circ} \mathrm{C}$ 以上の温度域で, スペクトルの形 を著しく変え，それどれの試料待有な 8 本拈よび 4 本構造を示 すことは 3.1 に述べた。ここで，S-2 が無定形領域のみの単一 相であり，S-1 が部分結晶化物であることを考えれば，室温で明 りょ となる S-1 の 8 本構造は, 結晶領域中のラジカルが寄与 するすのと考光られよう。このことは，図4に执いて S-2 のス

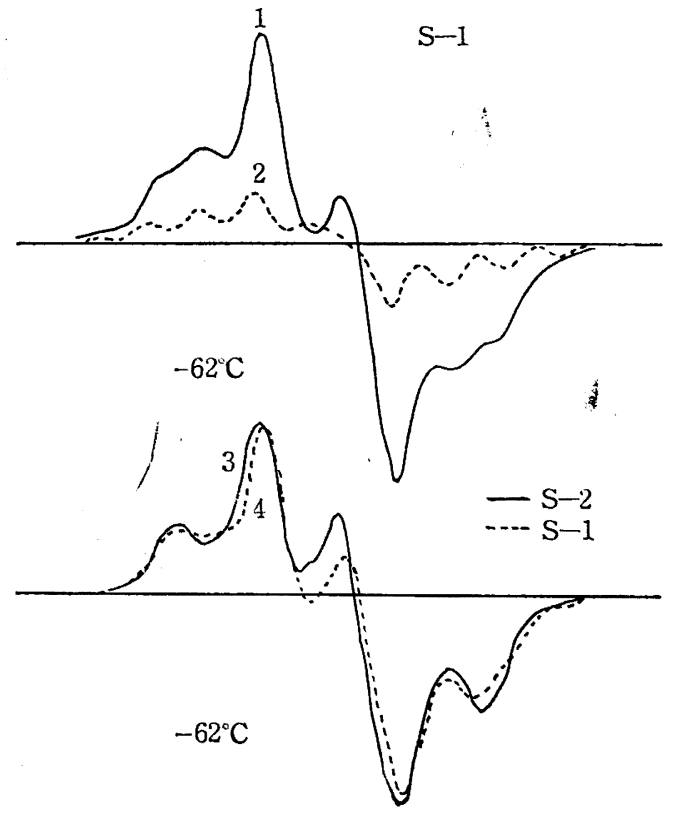

磁場の強さ

図 7 S-1 の結晶, 無定形領域におけるラジカルの分離 实線 1:S-1 のスペクトル（図 2) 破線 2:S-1 の8本瞥造スペクトル（因 3)

破線 3：S-1 のスペクトルから8 本槽造スペクトルを差し引いたもの 夹線 $4:$ S-2 の 4 本篮造スペクトル（図 4) 
ペクトルは，S-1の8本構造が明りょうとなる室温付近ではすで に消失していることからも理解される。また図 7 は, 両試料のスぺ クトルがその形を変える温度域の $-62^{\circ} \mathrm{C}$ では, S-1 の結晶領域 にのみ 8 本構造が存在することを証拠立てるるので, 図 2 の ESR スペクトル系列中, $-60^{\circ} \mathrm{C}$ 付近のものから, 図 3 の同温度付近 に拈ける8本構造スペクトルを差し引いたすのは, 図4 から得ら れる S-2 の 4 本構造スペクトルK一致することを示している。 しかしながら, 同じような羑し引きは, スペクトル形の変化が起 こり始める $-70^{\circ} \mathrm{C}$ 以下の温度域では成り立たず, したがって, 8 本構造は $-70^{\circ} \mathrm{C}$ 以上の温度域でラジカル種の变化により発生 するすのと推定される。

\section{$4 \cdot 2$ ラジカルの不対電子とプロトンとの相互作用}

1 個のラジカルとプロトン $n$ 個との磁気相互作用の結果は, 核スピン $I=1 / 2$ で各プロトン毎に量子化は $m_{I}= \pm 1 / 2$ の 2 方 向に行なわれるので，吸収線は $2^{n}$ 本になるが， $n$ 個が同等な相 互作用をるつ場合には，その5ち同じ位置に現われるすのがある ため, $1: n: \cdots \cdots ;{ }_{n} C_{R}: \cdots \cdots n: 1$ の強度比をるつ $n+1$ 本の吸 収線になって観測される。いま，S-1 の8 本構造スペクトルを考 えると図 8 のように三つの場合が可能である。すなわち, 図中 (A) はます゚ 3 個の近接プロトンによる同等な相互作用によって 大きくわかれた 4 本の吸収線を生じ,ささらにそれが離れた 1 個の プロトンによって小さく分けられて8本になった場合の吸収強度 比を示している。また（B）は，1個の近接プロトンにより大さ くわかれた 2 本の吸収線が現われ, さらにとれが 3 個の同等な相 互作用をるつプロトンによって 8 本の吸収線を生じた場合, 最後 に (C) は, 7 個のプロトンとの同等な相互作用により, 8 本の吸 収線を生じた場合である。S-1 から得られた本構造が (A), （B）の場合に当てはまらないことは，その積分曲線（吸収曲線） がこれらの強度比をるつ図形からかけ離れていることから知れ る。図 9 は, 図8の (C) の場合について吸収線の形を仮定して

$3 \mathrm{H}$

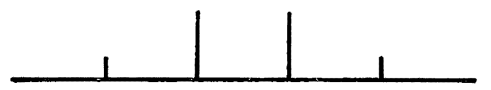

$\mathrm{H}$

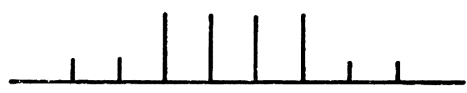

(A)

$\mathrm{H}$

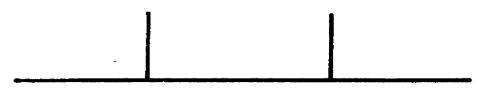

$3 \mathrm{H}$

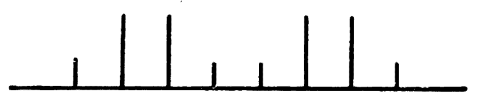

(B)

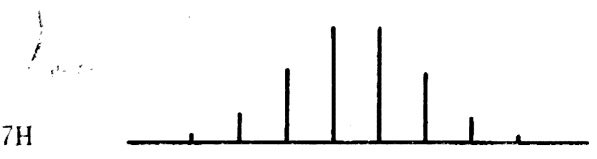

(c)

因 8

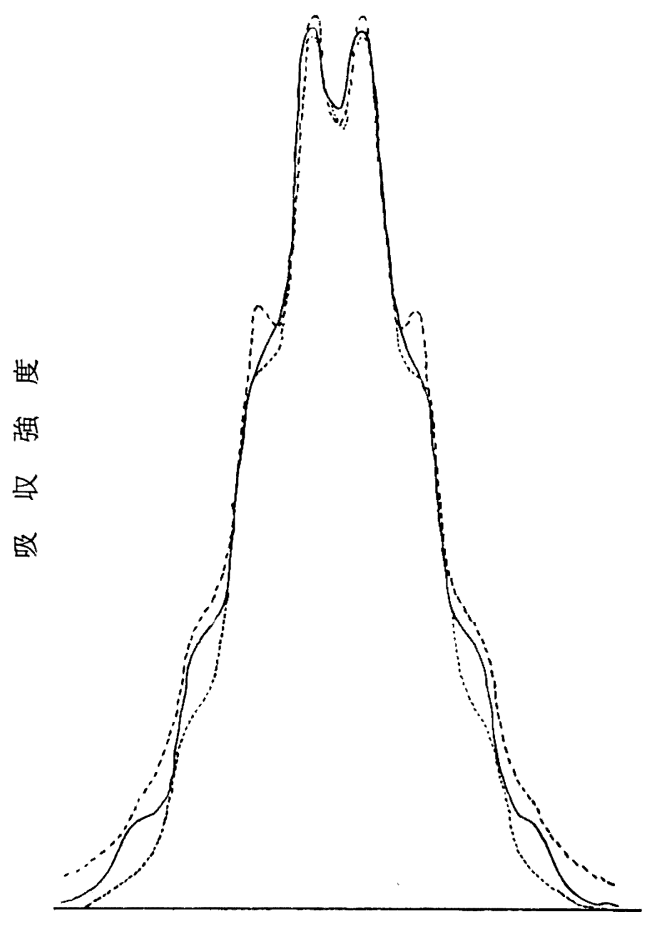

磁場の強さ

図98 本構造スペクトルの吸収曲線 ……: 理論曲線 (ガウス) , - - : 理論曲線 (ローレンシ), 一 : 实測

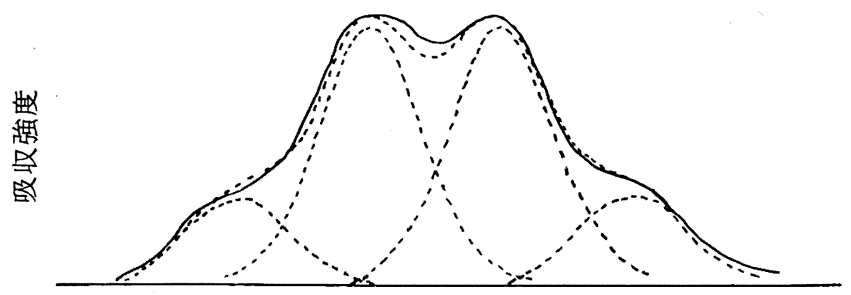

磁場の強さ

図104本構造スペクトルの吸収曲線 ---：理論曲線 (ガウス), 一：实測

行なった吸収曲線の理論計算値と実測値との比較をしたもので, 実測值は Lorentz 型と Gauss 型の中間に位置し, 仮定とよい一 致を見せている。眓 10 は同じような計算を S-2 の 4 本構造に ついて Gauss 型を仮定して行なったもので， 3 個のプロトンと の同等な相互作用という仮定を満足している。

\section{$4 \cdot 3$ ラジカル生成の機構}

$r$ 線照射により直接生じるラジカルの種類は，本質的に高分子 の化学構造によって異なることはあっても, その微細構造の影響 を受けることは考朰くい。また，4.2 に示した 8 本構造スペク トルの 7 個のプロトンとの同等な相互作用は, ポリブテン-1 の 化学構造から直接にはでてこないので, なんらかの原因によって, すでに存在していたラジカルがそのふんい気の影響を受けて形を 変えた結果であると考兄られる。図 11 は, これらラジカルの消 長を図式化したもので, 図中（A）の变化は， $\gamma$ 線照射によって 生じたラジカルに ( I ), (II) 二つの極限構造式が取られた場合で あって， 7 個のプロトンが不対電子と同等の相互作用を持つとす れば，（Ｉ），（II）の構造の共鳴によって８本構造を取ることが考

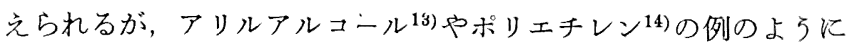

13) M. Fujimoto, D. J. E. Ingram, Trans. Faraday Soc. 54, 1304 (1958).

14) H. Kashiwabara, J. Phys. Soc. Japan 16, 2494 (1961). 


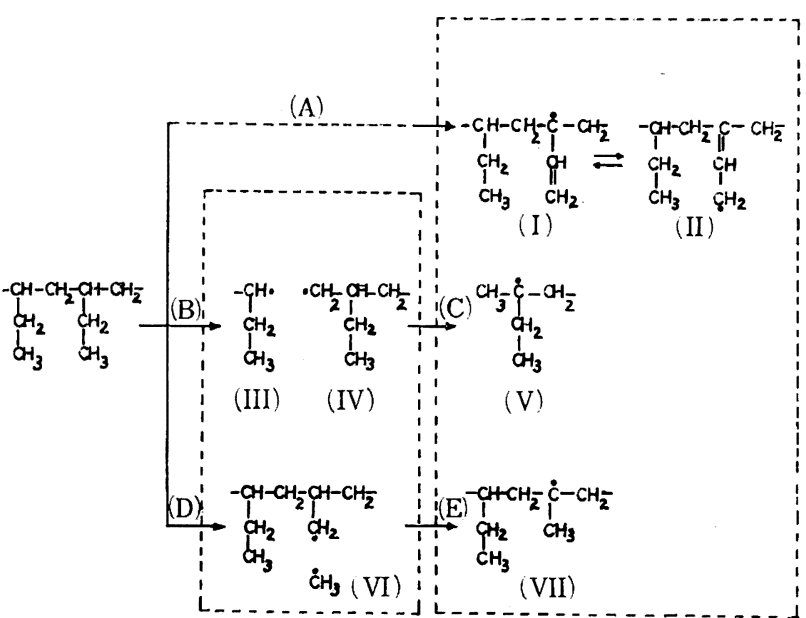

図 11 各種ラジカルの生成機構

アリル基の中央の炭素につくプロトンの相互作用は他のものと比 べて小さいと考兄られるので，このよ5な解釈は適当でない。そ の5光（I ），(II）の構造が結晶領域に存在すると考光ることは， 極限構造式の conformation からいって無理があるよ5に思われ るし，もし存在を許すとすれば，無定形領域には存在し得ないと い5理由も見出しにくい。（B)の変化は， $\gamma$ 線によって主鎖の妡 断が起こった場合を考学ている。一般に線状高分子の化学構造に 及ぼす放射線の効果は，発生したラジカルの反応に従って生じる 檴造变化の様式により, 架橋型もしくは切断型（またはその混合 型）に分けられて括り，ポリブテン-1 は室内照射の場合，架橋 切断の比をほぼ同じくする混合型であることが知られている15)。 図 7 亿示した照射による極限粘度の低下は，低温照射を行なった 著者らの実験に扣いても主鎖の切断がかなり起こっていることを 予想させる。この場合, 必然的に生じるのが (III)，(N) で示され るよ 5 な 6 本構造および 4 本構造をるつラジカルであり，低温で は両者が混在して観測されているのであろう。しかしながら，低 温での図形はかなりぼやけて物り，6 本構造と 4 本構造の分離は 困難である。図 2 飞見られる hfs は，その間隔が約 29 gaussで あるが，これはポリエチレンのアルキル型ラジカル16) $-\mathrm{CH}_{2}-\dot{\mathrm{C}} \mathrm{H}-$ $\mathrm{CH}_{2}$-が 6 本構造として観測された場合の間隔とほぼ一致するの

15）荒牧，植村，高柳，昭和 39 年 4 月，日本化学会第 17 年会.

16) E. J. Lawton, J. S. Balwit, R. S. Powell, J.Chem. Phys. $33,395(1960)$.
で, 図 11 の(III)に示される 6 本構造を生じるラジカル種存在の 支持となる。このラジカルは, 温度の上昇に伴って 4 本構造より 先に消失するるのと思われる。残った 4 本構造は，結晶領域中で は(C)の過程に従ってプロトンの移動が起こり，8本構造を生じ るラジカル（V)が出現すると考兄られる。（D)の過程は，質量ス ペクトルに認められたメタンが分子鎖の末端メチル基ではなく， 側鎖のメチル基の切断により発生したるのであると仮定した場合 でありこのときには主鎖切断の場合と異なって 6 本構造の出現 はないが，4 本構造 (VI) から 8 本構造 (VI) に移行する機構(E) は同じである。(V), (VI) の8本構造については，ESR スペク トルから得られる情報に関する限り，過程の別を問わず同じスペ クトルを与学るはずである。しかし，6本構造が存在しているこ と、また側鎖の熱運動は $\mathrm{NMR}^{2)}$ に打いて $-200^{\circ} \mathrm{C}$, また粘弾性 測定 ${ }^{3,17)}$ 飞执いて $-130^{\circ} \mathrm{C}$ 付近から認められていることなどか ら， $-60^{\circ} \mathrm{C}$ 飞至ってもラジカルが側鎖に保有されていると考兄 ることは困難で，やはり主鎖の切断による機構が支配的であると 考える方がよい。8 本構造を図中 (V), (VII) のラジカル種に同定 することについては，その hfs の間隔が Ohnishi らº のポリプ ロピレンについて報告された 33 gauss と一致することからも支 持されよう。最後に, 結晶領域中でのみ $(\mathrm{C}),(\mathrm{E})$ の過程でプロ トンの移動が起こるといらことの説明は, 推測の域を出ないが, 与えられた熱エネルギーが無定形領域では分子全体の熱振動の形 で分散され，その運動に伴ってラジカルは反応消失するのに対し， 分子運動が結晶格子内で扣制されている結晶領域では, ラジカル の反応のひん度が減じ, 熱エネルギーはより安定な 8 本構造への プロトンの移動に集約されるのではないかと考兄られる。

以上，著者らは高分子固体中に捕えられたラジカルが，その微 細構造と関連して変化することがあるとい5実験事実を報告した が，これは，組織中の分子運動とも密接な関係をもっていること が当然予想されるので, その方面について核磁気共鳴法の併用に よる実験を進めていることを付言する。

（第 13 回高分子学会年次大会発表）

本研究は昭和 37 年度文部省機関研究の一部であり，文部省当 局批よび質量スペクトルに便宜を与えられた九州大学理学部地質 学教室山口 勝博士に深く感謝する。

17) M. Takayanagi, Mem. Fac. Eng. Kyushu Univ. 23, 88 (1963). 